\title{
FREGE ON NEGATIVE JUDGEMENT AND ASSERTION*
}

\author{
Dirk Greimann** \\ dirk.greimann@gmail.com
}

RESUMO Frege discute dois tipos de negação em "Die Verneinung" (1918): uma semântica e uma pragmática. Negação semântica consiste na aplicação da função lógica denotada por 'é falso que p'para um pensamento, $e$ negação pragmática no ato de afirmar ou julgar um pensamento como falso. De acordo com a interpretação padrão, Frege não reconhece a negação pragmática, porque ela é logicamente redundante. Assim, ele rejeita a visão dualística clássica de que tanto verdade quanto falsidade são qualidades de julgamento e, em vez disso, adota a visão monística de que julgar é sempre reconhecer um pensamento como verdade. Meu objetivo neste artigo é mostrar que tal interpretação não pode ser sustentada. Apesar de Frege não endossar a visão clássica, ele defende um conceito dualista que é caracterizado pela afirmação de que julgar é uma operação binária que contém tanto o ato de reconhecer um pensamento como verdade, quanto o ato de rejeitar o pensamento oposto como falso. Para tornar essa interpretação plausível, Frege faz observações dualísticas sobre a negação em três escritos póstumos, que têm recebido pouca atenção até o presente, são analisadas em detalhe e seu background é reconstruido. Argumenta-se que Frege reconhece o julgamento negativo para explicar o papel epistêmico do ato de julgar na aquisição de conhecimento.

Palavras-chave Frege, negação, julgamento negativo, falsidade, Künne.

** Universidade Federal Fluminense. Niterói - RJ - Brasil. 
ABSTRACT In "Die Verneinung” (1918), Frege discusses two types of negation, a semantic one and a pragmatic one. Semantic negation consists in the application of the logical function denoted by 'it is false that $p$ ' to a thought, and pragmatic negation in the act of asserting or judging a thought as false. According to the standard interpretation, Frege does not acknowledge pragmatic negation, because it is logically redundant. He therefore rejects the classical dualistic view that both truth and falsity are qualities of judgement and adopts instead the monistic view that to judge is always to recognize a thought as true. My aim in this paper is to show that this interpretation cannot be sustained. Though Frege does not endorse the classical view, he defends a dualistic conception that is characterized by the claim that judging is a binary operation that contains both the act of recognizing a thought as true and the act of rejecting the opposite thought as false. To make this interpretation plausible, Frege's dualistic remarks on negation in three posthumous writings, which have received little attention so far, are analyzed in detail and their background is reconstructed. It is argued that Frege acknowledges negative judgements to account for the epistemic role of the act of judgement in the acquisition of knowledge.

Keywords Frege, negation, negative judgement, falsity, Künne.

\section{Introduction}

In Frege's logic, negation is understood as the ascription of falsehood to a thought. To say that snow is not white is the same as to say that it is false that snow is white. In "Die Verneinung" (1918), he distinguishes between two types of negation that we may call 'pragmatic' and 'semantic' negation, respectively. Semantic negation refers to the semantic content of judgements and assertions whereas pragmatic negation refers to the act of making an assertion or judgement. Negation in the pragmatic sense consists in the act of asserting or judging something as false. Such assertions and judgements may be called 'negative assertions' and 'negative judgements'. They are expressed by assertoric sentences of the form 'It is false that p', given that the sentential connective 'it is false that $\mathrm{p}$ ' is interpreted as an illocutionary act indicating devise representing the speech act of asserting something as false.

Negation in the semantic sense consists in the application of the sense of 'it is false that p' to the sense of a sentence. It is contained in the question 'Is it false that snow is white?' By making this question, we are not asserting the 
thought that snow is white as false, but we are asking the hearer to inform us about the truth value of the thought that it is false that snow is white. In this case, we do not consider 'it is false that p' as an illocutionary act indicating devise expressing a negative assertoric force, but as a logical operator expressing a logical function that maps a thought to the opposite thought. ${ }^{1}$

It is commonly assumed that Frege denies the existence of pragmatic negation. ${ }^{2}$ When we assert that that $\mathrm{p}$ is false, we are not really making a negative assertion, but we are making a positive assertion to the effect that the negative thought that it is false that $\mathrm{p}$ is true. The aim of this paper is to show that this reading of Frege must be revised, because it is incompatible with his remarks on negation in three posthumous writings that have hitherto received only little attention. They reveal that, for Frege, to judge is to make a choice between opposite thoughts that contains both a positive and a negative judgement. $\mathrm{He}$ considers judging to be a binary operation in which opposite truth values are assigned to opposite thoughts. In section 1 and 2, Frege's apparent rejection of negative judgements in his first and his second system is briefly recapitulated. In section 3, the textual material suggesting that he recognizes such judgements is presented. The task of section 4 is to show that he adopts a dualistic conception of judgement. To make this plausible, the epistemological and logical background of his dualistic remarks on negation is reconstructed. It is shown that Frege's recognition of negative judgements derives from the role he ascribes to the act of judgement in the formation of beliefs and the acquisition of knowledge. The task of section 5 is to clarify whether Frege's binary conception of judgements conflicts with the monistic notation of judgements in his formal language.

\section{Frege on Negative Judgement in His First System}

Frege's logic consists basically of a theory of inference and a theory of judgement. The task of the latter is to make the logical structure of judgements explicit. Frege holds that the grammatical structure of natural language often distorts the logical structure of the judgements that we express by means of its sentences. To make the logical structure explicit, he aims to construe a 'logically

1 See, for instance, Frege (1918, pp. 372 f.; 1997, p. 355). I always give two references to Frege's writings: first to the German original, and then to the English translation). Negative judgement is characterized by Frege as the 'polar opposite' (Gegenpol) of judgement in the normal positive sense, i.e., the act of acknowledging a thought as true. Semantic negation is described by him as the 'transition' (Übergehen) from a thought to the opposite thought.

2 See, for instance, Künne (2010, pp. 572-78). As far as I can see, Künne's reconstruction of Frege's account of negation is the most detailed and thorough reconstruction to be found in the literature. 
perfect language' whose sentences have a grammatical structure that depict the logical structure of the judgements they express in a faithful way.

According to the system of "Begriffsschrift", the logical form of assertoric sentences is always ' $\mid-A$ ', which may be read as 'The circumstance $A$ is a fact' or 'The judgeable content A is true'. The vertical stroke '|', called the 'judgement stroke', represents the act of 'affirmation' (Bejahung), that is, the speech act of asserting something as true (or a fact). The horizontal stroke '-' is the so-called 'content stroke'. Its task is to isolate the content of a judgement from the act of making the judgement. ' $-p$ ' expresses the same judgeable content as ' $\mid-p$ ', but without asserting this content as true.

According to the description of the syntax of the formal language in $\S 3$, the judgement stroke is the only predicate of the formal language. It may be read as 'is a fact'. The instances of ' $-\Delta$ ' are all sentence nominalizations that do not contain any predicates, but only functional signs and proper names. The sentence 'Archimedes was killed at the capture of Syracuse', for instance, is translated into the formal language by a sentence of the form of 'The violent death of Archimedes at the capture of Syracuse is a fact':

Imagine a language in which the sentence 'Archimedes was killed at the capture of Syracuse' is expressed in the following way: 'The violent death of Archimedes at the capture of Syracuse is a fact'. Even here, if one wants, subject and predicate can be distinguished, but the subject contains the whole content, and the predicate serves only to present it as a judgement. Such a language would have only one predicate for all judgements, namely, 'is a fact'. [...] Our Begriffsschrift is such a language and the symbol $\mid-$ is its common predicate for all judgements. (Frege 1879, §3; 1997, p. 57, partly my translation; original also in italics)

Frege's example suggests that we must translate 'Snow is white' as 'The whiteness of snow is a fact' into the language he asks us to imagine. From the point of view of "Begriffsschrift", the proper name 'the whiteness of snow' expresses the same propositional content as the assertoric sentence 'Snow is white', but without presenting this content as a fact. The nominalization achieves a separation of predication and assertion that Frege calls, in his later writings, the 'detachment of assertoric force from the predicate'. ${ }^{3}$ It is syntactically realized by replacing the predicates (like ' $\mathrm{x}$ is white') by functional signs ('the whiteness of $\mathrm{x}$ '). ${ }^{4}$

In $\S 7$, Frege introduces the 'negation stroke', which is the negation sign of his system: 
If a small vertical stroke is attached to the underside of the content stroke, then this is intended to express the circumstance that the content does not obtain. Thus, for example,

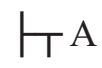

means 'A does not obtain'. I call this small vertical stroke the negation stroke. The part of the horizontal stroke to the right of the negation stroke is the content stroke of A, the part to the left of the content stroke, on the other hand, is the content stroke of the negation of A (Frege, 1879, §7; 1997, p. 60).

Since, in "Begriffsschrift", Frege still does not distinguish between 'sense' and 'reference' (Bedeutung), the function denoted by the negation stroke is not to be considered as a function mapping a truth value to the opposite truth value, but as a function mapping a circumstance to the opposite circumstance. The negation stroke corresponds in English to the functional sign 'the non-obtaining of A', which denotes the function mapping the circumstance A to the circumstance that A does not obtain. The sentence 'It is false that snow is not white' (or 'Snow is not white') must accordingly be translated into the nominalized fragment of English as 'The non-obtaining of the whiteness of snow is a fact'. The nominalization achieves here the 'detachment of assertoric force from negation', as it is called in Frege's later writings. ${ }^{5}$ Whereas, in natural language, assertion and negation are not clearly separated, because the connective 'it is false that p' can be interpreted as an illocutionary act indicating devise representing the speech act of asserting a thought as false, in the formal language assertion and negation are clearly separated, because the negation stroke, which is a functional sign like 'the non-obtaining of A', cannot be used to make a negative assertion.

Negation, so construed, is not a mental act, but a mathematical function that is a part of the semantic content of the sentences in which the negation stroke occurs. It is hence clear that that the negation stroke expresses the semantic type of negation, which refers to the contents of judgements. Frege's notation makes this syntactically visible by placing the negation stroke at the underside of the content stroke. Any logical operation occurring within the scope of the content stroke pertains to the content of judgements, and not to the act of judging. 
At the beginning of $\S 4$, Frege discusses in a general way which logical features pertain to the contents and which pertain to the act of judging. The logical features in question are those that are to be found in Kantian classification of judgements. He writes:

A distinction is drawn between universal and particular judgements: this is not really a distinction between judgements, but between contents. One ought to say: 'a judgement with a universal content', 'a judgement with a particular content'. For these properties belong to the content even when it is not presented as a judgement, but as a sentence. [...] The same applies to negation. In an indirect proof one says, for example: 'Suppose the lines $A B$ and $C D$ were not equal'. Here the content, that the lines $A B$ and $C D$ were not equal, contains a negation, but this content, although capable of being judged, is nevertheless not presented as a judgement. Negation therefore attaches to the content, irrespective of whether this appears as a judgement or not. I therefore hold it more appropriate to regard negation as a mark of a judgeable content (Frege, 1879, §4; 1997 , pp. 54-5, partly my translation; original also in italics).

In Kantian logic, negation is considered to be a mark of the act of judgement. ${ }^{6}$ He assumes that there are various manners of judgement, that is, various acts of judgement that differ with regard to the manner in which a content is judged. With regard to the 'quality' of judgements, for instance, we may make an affirmative or a negative judgement. ${ }^{7}$ In the first case, we accept a judgeable content as true while, in the second case, we reject such a content as false. The difference resides in the manner in which a judgement is made; it attaches to the act of judgement, and not to their content.

Contrary to this, Frege seems to reject the acknowledgement of negative judgement. He holds that, by making a judgement, we are always judging something as true. He considers the talk of negation in the sense of 'negative judgement' as logically misleading, because, in his view, any judgement is per se an affirmative judgement. In the literature, this view is sometimes called the 'monistic' view on the qualities of judgement. It contrasts with the classical dualistic view defended by Kant and others that both truth and falsity are qualities of judgements. ${ }^{8}$

Frege's argument against the dualistic conception is that it is possible to negate a thought without making any judgement at all. In the context of an indirect proof of a hypothesis $\mathrm{H}$, for instance, we assume the negation of $\mathrm{H}$, but without asserting it as true. A second example is the antecedens of the conditional sentence 'If snow is not white, then snow and milk differ in colour': 
it expresses a negation, but without asserting it as true, because, otherwise, the conditional sentence would be false. By negating a thought, we are hence merely advancing from one thought to the opposite thought, but we are not advancing from a thought to a truth value. The latter step is considered by Frege to be the characteristic of the act of judgement. ${ }^{9}$

\section{Frege on Negative Judgement in His Second System}

In "Die Verneinung" (1918) and kindred writings, Frege partly elaborates and partly revises his account of negation. The main revision is that, in his mature system, the negation stroke does not denote the function mapping a circumstances to the opposite circumstance, but the function mapping a truth value to the opposite truth value (and any other object to the False). We saw that, to dissociate assertoric force from the predicate, Frege nominalizes the sentences of natural language in his first system. The sentence 'Snow is white', for instance, is paraphrased as 'The whiteness of snow is a fact', where 'the whiteness of snow' contains the predication, and 'is a fact' the assertion. From the point of view of Frege's second system, this analysis involves a confusion of sense and reference. Whereas 'Snow is white' designates a truth value, its nominalization 'The whiteness of snow' designates a sense. The logical form of assertoric sentences is hence not 'The circumstance A is a fact', but 'The truth value $A$ is the True'. The instances of ' $A$ ' are sentences, considered as proper names of truth values. Accordingly, the judgement stroke in ' $\mid-A$ ' expresses that the truth value $\mathrm{A}$ is the True. ${ }^{10}$ Frege explains this in "Funktion und Begriff" (1891) as follows:

If we write down an equation or inequality, e.g. 5>4, we ordinarily wish at the same time to express a judgement; in our example, we want to assert that 5 is greater than 4 . According to the view I am here presenting, ' $5>4$ ' and ' $2+3=5$ ' just give us expressions for truth-values, without making any assertion. [...] We need thus a special sign in order to be able to assert something. To this end I make use of a vertical stroke at the left end of the horizontal, so that, e.g., by writing

$$
-2+3=5
$$

we assert that $2+3=5$. Thus we are not just writing down a truth-value, as in $2+3=5$,

but also at the same time saying that it is the True (Frege, 1918, pp. 136-137; 1997, p. 142). 
Accordingly, in the second system, the negation sign ' $T$ ' does not designate the function the non-obtaining of the circumstance $A$, but the function the truth value of the non-identity of the object $x$ with the True, which maps a truth value to the opposite truth value and any other object to the False. ${ }^{11}$

In "Die Verneinung", Frege argues that the separation of predication and assertion is also basic for the correct understanding of negation. The point of this separation is again to show that it is possible to negate a thought without making any judgement or assertion. The argument is parallel to the one in "Begriffsschrift":

It must be pointed out yet once more that to grasp a thought is not yet to judge; that we may express a thought in a sentence without asserting its truth; that a negative word may be contained in the predicate of a sentence, in which case the sense of this word is a part of the sense of the sentence, part of a thought; that by inserting a 'not' in the predicate of a sentence to be uttered non-assertively, we get a sentence that expresses a thought, as the original did. If we call such a transition, from a thought to its opposite, negating the thought, then negating in this sense is not coordinate with judging, and may not be regarded as the polar opposite of judging; for what matters in judging is always the truth, whereas we may pass from a thought to its opposite without asking which is true (Frege, 1918, p. 371 f.; 1997, p. 355).

Again, Frege seems to defend the monistic view of the qualities of judgement: negating must not be regarded as the polar opposite of judging, that is, as the act of judging something as false, because we may negate a thought without making any judgement at all. To judge is per se to acknowledge the truth of a thought.

Frege underpins the monistic approach by a second argument that is designed to show that the dualistic alternative is redundant in logic. His point of departure is the question whether there are two different manners of judging, an affirmative and a negative one:

What I have just been designating as the polar opposite of judging I will now regard as a second way of judging - without thereby admitting that there is such a second way. I shall thus be comprising both polar opposites under the common term 'judging'; this may be done, for polar opposites certainly do belong together. The question will then have to be put as follows: Are there two different ways of judging, of which one is used for the affirmative, and the other for the negative, answer to a question? Or is judging the same act in both cases? Does negating go along with judging? Or is negation part of the thought that underlies the act of judging? (Frege, 1918, p. 372; 1997, p. 356)

11 See Frege $(1893, \S 6)$. Given the semantic stipulations in this paragraph, Frege's infamous 'negation of the number 2 ' is true, because the number 2 is not the True. For a detailed reconstruction of this kind of negation, see Greimann (2007). 
Frege distinguishes here between a monistic and a dualistic sense of 'judging'. To judge in the monistic sense means always to acknowledge a thought as true. This is Frege's own official notion of judgement. But, for the sake of argument, he considers also a dualistic notion of judgement according to which the act of judging a thought as false is also a manner of judging. He accordingly introduces an expression for pragmatic negation, by stipulating that 'it is false that ...' represents the negative assertoric force: "If there is a special way of judging for when we deny, we must correspondingly have a special form of assertion. I may, e.g., say in this case 'it is false that ...' and lay it down that this must always have assertoric force attached to it" (Frege, 1918, p. 373; 1997, p. 356).

Frege then shows that, to formulate the laws of logic adequately, it is not sufficient to have a sign for pragmatic negation, but we need also a sign for semantic negation (like the negation stroke). Thus, there are instances of modus ponens in which the antecedens of the conditional sentence is a negative sentence, like in:

1. If snow is not white, then snow and milk are different in colour.

2. Snow is not white.

3. Snow and milk are different in colour.

Since, as Frege assumes, the premises of an inference must be asserted, we must read the second premise as a negative assertion. Its content is the positive thought that snow is white. The antecedens of the first premise, on the other hand, must not be asserted. Its content is the negative thought that snow is not white. Consequently, this antecedens and the second premise do not have the same content and modus ponens is not applicable. To resolve this problem, we must introduce semantic negation and positive judgement. ${ }^{12}$ From this Frege finally draws the following conclusion:

Thus the assumption of the two different ways of judging must be rejected. But what hangs on this decision? It might perhaps be regarded as valueless, if it did not affect an economy of logical primitives and their expressions in language. On the assumption of two ways of judging we need:

(1) assertoric force for affirmatives;

(2) assertoric force for negatives, e.g., inseparably attached to the word 'false';

(3) a negating word like 'not' in sentences uttered non-assertorically. 
If on the other hand we assume only a single way of judging, we only need:

(1) assertoric force;

(2) a negating word.

Such economy always shows that analysis has been pushed further, which leads to a clearer insight (Frege, 1918, p. 374; 1997, p. 357).

Again, Frege seems to be denying the existence of negative judgements. He explicitly rejects 'the assumption of the two different ways of judging', because the acknowledgement of both of them would offend against the maxim of minimizing the number of logical primitives. To explain this more closely, let ' $F_{t}$ ' be a 'positive judgement stroke' standing for the acceptance of a thought as true and let ' $F_{\mathrm{f}}$ ' be a 'negative judgement stroke' standing for the rejection of a thought as false. Let ' $T$ ' stand as usual for semantic negation. We can then say that the main thesis defended by Frege here is that the introduction of ' $F_{\text {, }}$, into the language of logic is redundant, because ' $F_{\mathrm{f}}$ ' can be reduced to ' $F_{t}$, and ' $T$ ' by translating ' $F_{f}-x$ ' as ' $F_{t} T x$ ', where ' $x$ ' is a name for any object.

How are we to understand this reduction? Given Frege's monistic view on the qualities of judgement, he cannot consistently affirm that, in order to make a judgement whose quality is falsity, it suffices to make the corresponding positive judgement. For, in this case, the reduction would imply the dualistic view that falsity is also a quality of judgement. If, for instance, by judging the thought that snow is not white as true (' $F_{\mathrm{t}} \mathrm{T}$ White(snow)'), we are also judging the thought that snow is white as false (' $F_{\mathrm{f}}-$ White(snow)'), then both truth and falsity are qualities of this judgement. ${ }^{13}$ To avoid this consequence, we must assume that the reduction Frege has in mind consists in the substitution of the act of judging a thought as false by a similar but different act, namely, the act of judging the opposite thought as true. In this case, he does not identify the negative assertion of a thought with the positive assertion of the opposite thought, but he eliminates negative assertion altogether, by replacing it by a similar but different speech act that contains only positive assertion and semantic negation. This view is a kind of 'monistic ersatzism'. It holds that we do not need falsity as a second quality because the speech act of asserting a given thought as false can always be replaced by the similar speech act of asserting the opposite thought as true without affecting the expressive power of our formal language in any logically relevant respect. This kind of ersatzism allows us to deny the existence of negative judgements in a consistent way. 


\section{The Conception of Negative Judgement in the Posthumous Writings}

There are three posthumous writings of Frege's mature period in which he explicitly acknowledges the existence of negative judgements. The first is the manuscript "Logik" from 1897. In the section about negation, Frege remarks: "When we are concerned with the truth of a thought, we waver between opposite thoughts, and with the same act we recognize one of them as true and the other as false" (Frege, 1897, p. 161; 1979, p. 149, partly my translation).

The second text is "Einleitung in die Logik", written in 1906. The relevant passage reads:

To each thought there corresponds an opposite, so that rejecting one of them always coincides with accepting the other. One can say that to make a judgement is to make a choice between opposites. Rejecting the one and accepting the other is one and the same act. Therefore there is no need of a special denomination, or a special sign, for rejecting a thought (Frege, 1906a, p. 201; 1979, p. 185, partly my translation; my emphasis).

The third text is "Kurze Übersicht meiner logischen Lehren", which is also written in 1906. The relevant passage is almost identical with the passage in "Einleitung":

To each thought there corresponds an opposite, so that rejecting one of them coincides with accepting the other. To make a judgement is to make a choice between opposite thoughts. Accepting one of them and rejecting the other is one act. So there is no need of a special sign for rejecting a thought. We only need a special sign for negation as such (Frege, 1906b, p. 214; 1979, p. 198).

Clearly, Frege adopts here a dualistic view according to which truth and falsity are both qualities of judgement. Its main thesis is that to judge is to make a choice between opposite thoughts to the effect that one of them is accepted as true and the other is rejected (or recognized) as false. This act is not considered by him to be a complex act consisting of two judgements, but as a single act: to acknowledge a thought as true and to reject the opposite thought as false are one and the same act. Clearly, this implies that any positive judgement involves a negative one. Frege is thus committed to acknowledge negative judgements; he cannot consistently deny their existence.

Frege concludes from his discussion of negation in both the "Einleitung" and the "Übersicht" that 'there is no need of a special sign for rejecting a thought', that is, the introduction of a negative judgement stroke (like ' $F_{f}$ ') is logically redundant. The obvious reason is that ' $F_{f}$ ' can be defined in terms of ' $F$ ', and ' $T$ ': since ' $F_{\mathrm{f}}-\mathrm{x}$ ' and ' $F_{\mathrm{t}} \mathrm{T} \mathrm{x}$ ' always express the same judgement, ' $F_{\mathrm{f}}-\mathrm{x}$ ' can be defined as ' $F_{\mathrm{t}} \mathrm{T} \mathrm{x}$ '. Thanks to this definition, any sentence containing 
' $F_{\mathrm{f}}$ ' can be translated into a sentence that does not contain this stroke. The introduction of a negative judgement stroke is hence redundant in logic. For this reason, Frege finally rejects the introduction of a negative judgement stroke into his logical language. ${ }^{14}$

It has become evident, I think, that Frege does not adopt a monistic view on the qualities of judgement, but only a monistic view on the linguistic representation of judgements with regard to their quality in a logically ideal language. In order to fulfil the requirement of minimizing the number of logical primitives, every judgement must be formulated in terms of the positive judgement stroke.

\section{The Dualistic Conception of Judgement}

Although Frege does recognize falsity as a quality of judgement, it would be wrong to ascribe to him a dualistic account of judgement in the classical sense. According to the classical view, every judgement has a single quality. The class of affirmative judgements and the class of negative judgements are mutually exclusive. By contrast, Frege holds that both truth and falsity are qualities of every judgement. For him, there is only a single manner of making a judgement that can be correctly described both as an affirmative and a negative judgement. When we recognize a thought as true, we are ipso facto recognizing the opposite thought as false, and vice versa. There are two qualities but only a single class of judgements that corresponds to them.

Moreover, the assumption that affirmative and negative judgements form mutually exclusive classes would generate an infinite regress in Frege's conception. Assume that the recognition of a thought A and the rejection of the opposite thought non-A are different judgements with different qualities of which the act of making a choice between these thoughts is composed. To judge $\mathrm{A}$, we must then make a choice between $\mathrm{A}$ and non-A, and, to reject non- $\mathrm{A}$, we must make a choice between non-A and the opposite thought non-non-A, and so on. To avoid this regress, we must assume that to recognize a thought as true and to reject the opposite thought as false are one and the same act.

Why does Frege adopt a dualistic conception? To see this, we must look both at his epistemology and at his logic.

\subsection{The Epistemological Background of the dualistic conception}

Frege's epistemology is based on the distinction between the act of merely grasping a thought, called 'thinking', and the act of recognizing the truth of 
a thought, called 'judging'. In "Der Gedanke" (1918), Frege motivates this distinction by means of the following example: "An advance in science usually takes place in this way: first a thought is grasped, and thus may perhaps be expressed in a propositional question; after appropriate investigations, this thought is finally recognized to be true" (Frege 1997, p. 330).

Suppose $\mathrm{S}$ is a scientist working in the field of neutrino physics. The starting point of his investigations is the question of whether neutrinos have a rest mass. At the beginning of his inquiries, this is an open question for $\mathrm{S}$. Both the thought that neutrinos have a rest mass and the opposite thought are candidates for the right answer. At a later stage, when $\mathrm{S}$ has gathered some evidence, he might form the hypothesis that neutrinos have a rest mass. But he still leaves open the question as to whether the hypothesis is true. The hypothesis is only a conjecture, an assumption, and not a belief. To answer the initial question, S must finally make a choice between two possible answers, 'yes' and 'no'. By making this choice, $\mathrm{S}$ forms a belief, that is, he takes one of the possible answers to be true. If the belief is true, he acquires new knowledge. If the belief is false or neither true nor false, he commits an error. ${ }^{15}$

From this epistemic perspective, to judge is to advance from a question to a belief, by making a choice between two alternative answers, with the intention to acquire knowledge. In this context, to make a choice means to prefer one option over another to achieve a certain goal. We are giving preference to one possible answer over the alternative answer by recognizing the first as true and rejecting the second as false. The goal is to acquire knowledge or, at least, to avoid error. This explains why Frege acknowledges negative judgements. In his view, to judge is to make a choice between two possible truth value distributions over opposite thoughts with the intention to acquire knowledge. His approach is hence characterized by the claim that judging is a binary operation in which opposite truth-values are assigned to opposite thoughts. It implies that, by making a judgement, we are both recognizing a thought as true and rejecting the opposite thought as false. ${ }^{16}$

Markus Stepanians and Mark Textor have criticized Frege on the ground that there are cases in which we are making a judgement without making a choice between opposite thoughts. They hold that the acknowledgement of the truth of an axiom is a clear example of this. Textor writes:

15 See, for instance, Frege (1997, p. 158).

16 It is controversial whether Frege's notion of judgement is factive; see, for instance, the discussion in Kremer (2010). On the factualist reading, we can recognize the truth of a thought only when the thought is true. My thesis that Frege's notion of judgement is a binary notion is neutral in this regard. On the factive reading, the binary notion implies that we can recognize a thought as false only when the thought is false. 
Now consider judging that $1=1$. When I make this judgement I do not make up my mind between the thought that $1=1$ and its opposite. [...] A rational thinker simply has not alternative to judging that $1=1$ and, more importantly, there is neither the need nor the possibility to make up one's mind whether $1=1$ (Textor, 2010, p. 19).

Textor seems to read Frege in such a way that by judging he understands rational judging. To choose between opposite thoughts means then to select the thought that can be rationally asserted. Since there is no epistemic situation in which a rational thinker asserts that $1 \neq 1$, the judgement that $1=1$ does not really involve a choice between opposite thoughts. Moreover, as Stepanians (1998, p. 188) stresses, Frege holds that the truth of an axiom is evident from its sense. From this he infers that Frege is committed to the view that 'the understanding of an axiom implies the recognition of its truth'.

In my view, both objections are partly unjustified. First, it is highly doubtful that, for Frege, to judge is per se to make a rational judgement. His example in "Grundgesetze" of a madman making inferences that contradict our logical laws presupposes that the madman is able to make judgements, though only irrational ones. ${ }^{17}$ Second, an axiom is not self-evident in the sense that, by grasping its sense, we are already judging it as true. Consider, for instance, the first axiom of "Grundgesetze", which can be transcribed as "If $p$, then (if q, then $\mathrm{p}$ )'. Although this axiom is self-evident in the sense that its content already guarantees its truth, this may not be evident for a reader. For this reason, Frege gives a kind of correctness proof that is designed to make it evident that the axiom is self-evident. ${ }^{18}$ Hence, it is perfectly possible that a rational thinker wavers between the axiom and the opposite thought. There is only one epistemological constrain a thinker has to observe: when he wishes to make a judgement in Frege's sense, he cannot recognize both a thought and the opposite thought as true. From Frege's point of view, a radical inconsistent thinker does not make any judgement at all, because he is does not reject the thought as false which is the opposite of the thought he recognizes as true.

Nevertheless, Textor's and Stepanians' criticism hints at an important point, I think. Frege's binary conception of judgement applies only to a special class of judgements that are made under the specific epistemic circumstance that the speaker considers two opposite answers to a question. This is not always the case. Someone who already knows that snow is white goes on to assert that snow is white, but without considering the counter hypothesis that snow might 
not be white. This restriction must not to be seen as defect of Frege's account. He is interested only in scientific judgements. Hence, the class of judgements that is relevant for him is only the class of those judgements that are designed to extend our knowledge. The paradigm of such judgements is the discovery of a new fact.

Note that Frege's characterization of judgement as a choice between opposite thoughts is complementary to his standard 'definition' (or 'elucidation') of judging, according to which to judge is to acknowledge the truth of a thought. The task of the standard definition is to distinguish between the act of grasping a thought and the act of acknowledging its truth. The definition of judging in terms of a choice specifies what exactly we are doing when we acknowledge the truth of a thought. It suggests the following refinement of the standard definition: when we acknowledge the truth of a thought, we are ipso facto rejecting the opposite thought as false, and vice versa.

\subsection{The Logical Background of the Dualistic Conception}

We have seen that Frege's epistemology explains why he considers the act of judgement as a choice between opposite thoughts. However, this explanation is not sufficient to explain his conception completely, because it does not explain why he identifies the act of recognizing a thought as true with the act of rejecting the opposite thought as false. We can account for the binary character of judging without making this identification. To be sure, by recognizing a thought as true, we are indirectly rejecting the opposite thought as true, because the truth of the first thought implies the falsity of the second. When we answer the question 'Is it true that neutrinos have a rest mass?' with 'yes', we have indirectly answered the complementary question 'Is it false that neutrinos have a rest mass?' with 'no', because it would be inconsistent to answer both questions with 'yes'. Still, it does not follow that the two answers express the same judgement. A binary judgement seems to be complex judgement composed of two simple judgments. Moreover, from a linguistic point of view, the sentences 'I affirm that neutrinos have a rest mass' and 'I deny that neutrinos do not have a rest mass' express different illocutionary acts with different propositional contents. Hence, they express different judgements.

To see why Frege identifies such judgements, we have to take into account his conception of double negation. In the section about negation in 'Logic' (1897), he writes:

Thus it is clear that when I assert that Peter did not come to Rome, the act of asserting and judging is no different from when I assert that Peter did come to Rome, the only difference is that we have the opposite thought. [...] To declare false the thought that 
Peter did not come to Rome is to assert that Peter came to Rome. We could declare it false by inserting a second 'not' and saying 'Peter did (not) not come to Rome' or 'It is not true that Peter did not come to Rome'. And from this it follows that two negatives cancel one another out. If we take the opposite of the opposite of something, we have what we began with.

When we are concerned with the truth of a thought, we waver between opposite thoughts, and with the same act we recognize one of them as true and the other as false (Frege, 1897, p. 161; 1979, p. 149, partly my translation).

In the first paragraph, Frege aims to show that double semantic negation is a redundant manoeuvre that does not alter the semantic content of a sentence, that is, the sentences ' $F_{\mathrm{t}}-\mathrm{x}$ ' and ' $F_{\mathrm{t}} \mathrm{T}_{\mathrm{T}}^{\mathrm{x}}$ ' express the same thought. This thesis can be derived from the semantics in "Grundgesetze". We have seen that the negation sign ' $T$ ' denotes a function mapping the True to the False and the False to the True. Consequently, the double negation sign 'TT' denotes the trivial and completely redundant function that maps the True to the True and the False to the False. It is equivalent to the sentential connective 'it is true that p' in natural language, which also maps the True to the True and the False to the False. Hence, the sentences ' $F_{\mathrm{t}}-\mathrm{x}$ ' and ' $F_{\mathrm{t}} T_{\mathrm{T}} \mathrm{x}$ ' have the same truth conditions. ' $F_{t}-x$ ' denotes the True if and only if ' $F_{t} T T x$ ' denotes the Tue.

In $\S 32$ of "Grundgesetze", Frege identifies the thought expressed by an assertoric sentence with the conditions under which this sentence denotes the True. Since double negation preserves the truth conditions of sentences, this implies that the sentences ' $F_{t}-\mathrm{x}$ ' and ' $F_{\mathrm{t}} T_{\mathrm{T}} \mathrm{x}$ ' express the same thought.

In a similar way we can show that the pragmatic negation of the semantic negation of a sentence has the same truth conditions as the original sentence, that is, ' $F_{t}-x$ ' and ' $F_{f} T x$ ' have the same truth-conditions and hence the same sense. We have seen that the judgement stroke in ' $F_{t}-x$ ' expresses the identity of $-x$ with the True, where $-x$ is the truth value of a thought. The judgement-stroke is therefore an illocutionary truth-operator representing the speech act of asserting a thought as true. Its counterpart in natural language is the 'assertoric form' of a sentence, which Frege considers to be the main truth operator of natural language. ${ }^{19}$

Analogously, we must interpret the negative judgement-stroke in ' $F_{\mathrm{f}}-\mathrm{x}$ ' as an illocutionary truth operator expressing the identity of $-\mathrm{x}$ with the False. It represents the speech act of asserting a thought as false. Obviously, 
the negative assertoric sentence ' $F_{\mathrm{f}}-\mathrm{x}$ ' is true if and only is the truth value $-\mathrm{x}$ is the False. It follows, again, that the positive assertion of a thought and the negative assertion of the opposite thought always have the same sense, because the conditions under which the affirmative sentences ' $F_{t}-x$ ' denotes the True are identical to the conditions under which the negative sentence ' $F_{f} T \mathrm{x}$ ' denotes the True.

From a logical point of view, there is hence no difference between the recognition of the truth of a thought and the recognition of the falsity of the opposite thought. This finally explains why Frege identifies the act of rejecting a thought as false with the act of acknowledging the opposite thought as true.

\section{The Coherence of Frege's Overall Conception of Negation}

At first glance, Frege's dualistic conception of judgement conflicts with the monistic notation of judgements in his formal language. The price he is paying for the economy of primitives is that his notation suffers a lack of logical transparency: it does not faithfully depict the dualistic structure of judgements. To make this structure explicit, we must construe the contents of judgements by ordered pairs consisting of opposite thoughts, and we must construe the act of judgement as a binary operation that assigns a truth value to both members of these pairs. Since Frege represents only the act of recognizing a thought as true, his notation hides the binary character of the truth valuation contained in judgements. It does not capture the choice between opposite thoughts.

To defend Frege against this objection, we can show that, from his point of view, it does not really make sense to distinguish between affirmative and negative judgements at all. We can only distinguish between negative and affirmative assertoric sentences in the formal language, by defining that a negative assertoric sentence is a sentence that contains the negative judgement stroke, but we cannot also distinguish between negative and affirmative judgements, because the syntactic difference between sentence pairs of the form ' $F_{f}-x$ ' and ' $F_{\mathrm{t}} \mathrm{T}^{\mathrm{x}}$ ' is not reflected by a corresponding difference between the judgements they express.

This view is also suggested by Frege's remark $\S 4$ of "Begriffsschrift" that the classical distinction between categorical, hypothetical and disjunctive judgements seems to have 'only grammatical significance'. According to Frege's criterion of identity for conceptual contents, two sentences express the same content if they are logically equivalent. Since the conditional sentence 'If $\mathrm{p}$, then q' and the disjunctive sentence 'Not p, or q' are logically equivalent, they have the same content. As a consequence, it does not really make sense to speak of conditional and disjunctive judgements, because the syntactic difference between conditional 
and disjunctive sentences is not reflected by a difference between their contents. We cannot say that the conditional judgements are the judgements expressed by a conditional sentence, because the same judgements are also expressed by the corresponding disjunctive sentences. Taken by itself, such a judgement is neither a conditional nor a distributive judgement. Nevertheless, it can be correctly presented both as a conditional and as a distributive one. When we express it by a sentence of the form 'If $\mathrm{p}$, then q', then we presenting it as a conditional judgement, and when we express it by a sentence of the form 'Not p, or q', we are presenting it as a distributive one. It does not follow that the notation of a judgement by a conditional or a distributive sentence is logically misleading because, taken by itself, the judgement is neither a conditional or a distributive one. There is no hidden structure to be made explicit by the logical notation.

By the same token, we cannot say that an affirmative judgement is a judgement expressed by a sentence of the form ' $F_{t}-x$ ', because the same judgement is also expressed by a sentence of the form ' $F_{f} T \mathrm{x}$ '. Taken by itself, a judgement is neither an affirmative nor a negative one. This does not mean, again, that it is logically misleading to present a judgement as an affirmative or a negative one. It is correct to present it in both ways.

The advantage of Frege's monistic notation over the binary notation is that it makes the goal of judgements more explicit. From an epistemological point of view, there is an asymmetry between truth and falsity. The goal of making judgements in science is to discover truths and not falsities. To make this goal explicit, we must give preference to the act of recognizing a thought as true in our notation. The monistic notation answers this demand by presenting judgements as affirmative ones.

\section{Conclusions}

The conclusion to be drawn is that the standard interpretation of Frege's conception of negation must be revised. Frege does not defend a monistic view of the qualities of judgement, but a dualistic one that is characterized by a binary conception of the assignment of truth values in judgements.

There is also a more indirect conclusion to be drawn. In the secondary literature, it is commonly assumed that Frege reduces the speech act of assertion to the act of referring to a special object, viz. the True. To judge that snow is white is to make the attempt to refer to the True via the thought that snow is white. ${ }^{20}$ This reduction is attributed to Frege on the ground that he reduces 
assertoric sentences to proper names by means of the reductive definition that an assertoric sentence is a proper name whose reference is a truth value. In a series of former papers, I have argued that this reductive account of assertion and assertoric sentences cannot be ascribed to Frege. ${ }^{21}$ According to the syntax and the pragmatics of "Grundgesetze", assertoric sentences are not a species of proper names, but a category sui generis, and assertion is not a special kind of reference, but an act sui generis that consists basically in the act of presenting a thought as true. ${ }^{22}$

Our current result confirms this alternative interpretation. On the nonreductive reading, Frege claim that an affirmative judgement can be correctly described also as a negative one implies that the act of presenting a thought as true can also be correctly described as an act of presenting the opposite thought as false. Given the reductive interpretation, on the other hand, Frege's claim hardly makes sense. It implies that, by making an attempt to refer to the True via a given thought, we are ipso facto making an attempt to refer to the False via the opposite thought. Obviously, this implication is absurd. Nor does the reductive interpretation account for binary character of judgments. By making an attempt to refer to opposite truth values via opposite thoughts, we are not giving preference to any of these thoughts. The idea of rejecting a thought in favour of the opposite thought is lost. This is another reason why the reductive interpretation cannot be sustained.

\section{References}

FREGE, G. (1879). "Begriffsschrift, eine der arithmetischen nachgebildete Formelsprache des reinen Denkens". (pp. V-88). Reprinted in his "Begriffsschrift und andere Aufsätze". Hildesheim: Olms, second edition, 1988. Originally published by Louis Nebert in Halle. . (1891). "Funktion und Begriff". Jena: Hermann Pohle. Reprinted in: Frege, 1990, pp. 125-42.

. (1893). "Grundgesetze der Arithmetik. Begriffsschriftlich abgeleitet". Vol. 1. Jena: Hermann Pohle. Reprint: Darmstadt: Wissenschaftliche Buchgesellschaft, 2nd. ed. 1962.

. (1897). “'Logik'. Posthumous writing”. In: Frege, 1983, pp. 137-63.

. (1906a). "“Einleitung in die Logik'. Posthumous writing”. In: Frege, 1983, pp. 201-12.

. (1906b). “Kurze Übersicht meiner logischen Lehren'. Posthumous writing”. In: Frege, 1983, pp. 213-218. 
. (1918). “'Die Verneinung. Eine logische Untersuchung'. Beiträge zur Philosophie des deutschen Idealismus". 1. Reprinted in: Frege, 1990, pp. 342-78.

. (1979). "Posthumous Writings". Ed. by H. Hermes, F. Kambartel and F. Kaulbach, and tr. by P. Long and R. White. Oxford: Basil Blackwell. Engl. trans. of the first edition of: Frege. "Nachgelassene Schriften und Wissenschaftlicher Briefwechsel". Band 1. Ed. by H. Hermes, F. Kambartel and F. Kaulbach, Hamburg: Meiner, 1969. . (1983). "Nachgelassene Schriften und Wissenschaftlicher Briefwechsel". Vol. 1. Ed. by H. Hermes, F. Kambartel and F. Kaulbach. Hamburg: Meiner, second and extended edition (first published in 1969).

. "Kleine Schriften”. Ed. by I. Angelelli, second edition. Hildesheim: Olms, 1990. 1997.

. "The Frege Reader". Ed. and introduced by Michael Beaney. Oxford: Blackwell,

. "Basic Laws of Arithmetic". Engl. translation of Frege 1893. Oxford: Oxford University Press, 2013.

GREIMANN, D. "The Judgement-Stroke as a Truth-Operator: A New Interpretation of the Logical Form of Sentences in Frege's Scientific Language". Erkenntnis, 52, pp. 213-238, 2000. 2007.

. “A Negação Fregeana do Número 2”. O Que nos Faz Pensar, 23, pp. 41-51,

. "Does Frege Use a Truth-Predicate in his Justification of the Laws of Logic?". Mind, 117, pp. 403-425, 2008

HECK, R., MAY, R. "Frege's Contribution to Philosophy of Language”. (pp. 3-39). In: E. Lepore, B. Smith. The Oxford Handbook of Philosophy of Language. Oxford: Oxford University Press, 2006.

KANT, I. (1781). "Critique of Pure Reason". Second edition 1787, electronic edition, www.arts.cuhk.edu.hk/Philosophy/Kant/cpr.

KREMER, M. "Judgement and Truth in Frege". Journal of the History of Philosophy, 38, pp. 549-581, 2010.

KÜNNE, W. "Die Philosophische Logik Gottlob Freges”. Klostermann: Frankfurt am Main, 2010.

STEPANIANS, M. "Frege und Husserl über Urteilen und Denken”. Paderborn: Ferdinand Schöningh, 1998.

TEXTOR, M. "Frege on Judging as Acknowledging the Truth". Mind, 119, pp. 615655,2010 . 